\title{
NMES
}

New Middle Eastern Studies

ISSN: 2051-0861

Publication details, including guidelines for submissions:

https://journals.le.ac.uk/ojs1/index.php/nmes

\section{Non-Western Modernities in the Middle East: The Israeli Experience of Development and Social Change}

Author(s): Erdem Sarıaydın

To cite this article: Sarıaydın, Erdem (2020) "Non-Western Modernities in the Middle East: The Israeli Experience of Development and Social Change", New Middle Eastern Studies 10 (1), pp. 83-106.

Online Publication Date: 14 December 2020

\section{Disclaimer and Copyright}

The NMES editors make every effort to ensure the accuracy of all the information contained in the journal. However, the Editors and the University of Leicester make no representations or warranties whatsoever as to the accuracy, completeness or suitability for any purpose of the content and disclaim all such representations and warranties whether express or implied to the maximum extent permitted by law. Any views expressed in this publication are the views of the authors and not the views of the Editors or the University of Leicester.

Copyright New Middle Eastern Studies, 2020. All rights reserved. No part of this publication may be reproduced, stored, transmitted or disseminated, in any form, or by any means, without prior written permission from New Middle Eastern Studies, to whom all requests to reproduce copyright material should be directed, in writing.

\section{Terms and Conditions}

This article may be used for research, teaching and private study purposes. Any substantial or systematic reproduction, re-distribution, re-selling, loan or sub-licensing, systematic supply or distribution in any form to anyone is expressly forbidden.

The publisher does not give any warranty express or implied or make any representation that the contents will be complete or accurate or up to date. The accuracy of any instructions, formulae and drug doses should be independently verified with primary sources. The publisher shall not be liable for any loss, actions, claims, proceedings, demand or costs or damages whatsoever or howsoever caused arising directly or indirectly in connection with or arising out of the use of this material. 


\title{
Non-Western Modernities in the Middle East: The Israeli Experience of Development and Social Change
}

\author{
Erdem Sarıaydı*
}

\begin{abstract}
Could the unique and divergent modernization experiences of non-Western societies be the proof of a challenge to Western modernity? Could Israel be evaluated as a nonWestern modernity model in contrast to the common assumption that Israel is a Western country? This article hinges on the argument that the State of Israel is not a Western country as its type of modernity has significantly diverged from the globalization thesis claiming to eventually unite all societies around Western modernity. This argument is based on a non-Western modernization perspective inspired by the insights of the Multiple Modernities Paradigm (MMP) and the Uneven and Combined Development Theory (U\&CD). Today, Israel can be regarded as an economically modern society as it is a highly industrialized and urbanized society with high average living standards. However, what is the most remarkable fact observed in Israeli economic trajectory is that Israeli economic development has been mostly driven by state-led initiatives rather than by private initiatives such as a capitalist bourgeoisie class in the Western trajectory (France, Britain and the USA) where capitalist bourgeoisie class has become primary initiator and driving force of economic modernization. Moreover, this economic divergence naturally impacted on all other transformation trajectories of Israel such as its democratization and secularization processes. Contemporary Israel is neither a fully secularized society nor a liberal democratic one as the Eurocentric globalization thesis expected it to be after a long and arduous process of modernization. Therefore, the case of Israel shows that modernization processes do not follow a fixed, single and determinate way as they produces unexpected and uneven patterns, particularly in non-Western societies - even if they try to Westernise.
\end{abstract}

Keywords: Israel; Modernization; Secularism; Economic Development; Democratization; Multiple Modernities; Uneven and Combined Development

\section{Introduction}

Socio-political depiction of state/societies as "Western" is a common way of labelling a country although many of them are not based on a comprehensive and integrated analysis. The overwhelming military and economic supremacy of Western states such as the USA and Great Britain since the late 18th century, and later the globalization discourse, precipitated ${ }^{*}$ Erdem Sariaydın, PhD Candidate in International Relations and Regional Studies at Atatürk Strategic Research
Institute, National Defence University, Istanbul, Turkey. Email: erdemsaraydn@ gmail.com 
the idea of a single and unilinear direction of humanity to modern society which is mainly characterized as secularized, democratic and capitalist. This clearly meant that the fate of different societies is attached to that of Western societies, namely the Western Europe and the USA (Göksel 2017: 145-147; Göksel 2018b: 33-38). Therefore, societies embarking on a modernization program have been depicted as Western even though they are geographically and, perhaps culturally, located far away from the Western civilization.

The State of Israel has been depicted as a country representing characteristics of Western societies - the USA and Western Europe - which are predominantly capitalist, democratic and secular. The founding father of the establishment of a Jewish state in Palestine, Theodor Herzl had envisioned a Europeanized modern Jewish state which would serve as an outpost of "civilization against Asia and barbarism" (Herzl 1934). This Eurocentric vision has gradually turned into a dominant discourse that claims that the State of Israel has been standing in defence of supposedly Western values such as democracy and human rights in the Middle East. For instance, the former Spanish Prime Minister and politician Jose Maria Aznar has described Israel as the "centrepiece of Western civilization" (Isserovitz 2015). Also, the tendency to describe Israel as "the only democracy in the Middle" is a common argument lacking an in-depth analysis (Beilin 1992). Israel's strategic alliance and cooperation with Western states, especially with the USA, has ostensibly made this discourse more justifiable in the eyes of public opinion. Although such claims generally have not been grounded on a well-suited, objective and comprehensive framework, it seems that it is a natural inference stemming from a superficial look at the differences between Israel and the Arab world in a broad sense. In this way of thinking, relative indicators such as high living standards and more stable democracy unavoidably are claimed to place Israel firmly in the Western camp of modern societies (Barnett 1996: 5-6).

Recently, non-Western modernization studies have come to the forefront of public debates with intensive attention on development experiences that emerged in Asia and in Muslim-majority societies. While the "Japanese model" and so-called "Asian values" have become the primary focus in Asian studies, the "divergence or discrepancy of Islamic values" has been the primary focus in studies of Muslim countries (Göle 2000: 159). However, the experience of Jewish people who dominate Israeli society today has been mostly overlooked in these modernization studies. As it has gained independence relatively late compared to Western states, the Israeli modernization experience occupies a remarkable place amongst modern societies. Furthermore, as it has been frequently in conflict with its Arab neighbouring countries form the earliest day of its statehood, studies on Israeli society focus mostly on national security and military issues. Modernization studies rarely examine the contemporary Israeli society, which creates a scholarly gap in terms of a comprehensive and consistent perspective on Israeli experience vis-à-vis the supposedly modern societies (Adelman 2008: 9-10). The lack of such a perspective in analyses on Israeli society is a hinderance for assessing modern Israeli society more consistently.

This article seeks to provide a comprehensive theoretical perspective through modernization studies for understanding the Israeli modernity consistently and comparatively within its own historical context. The article seeks to develop a non-Western modernization perspective inspired by the works of Oğuzhan Göksel $(2015 ; 2016 ; 2018 \mathrm{a})$ and apply such a framework to the case of Israeli modernity. As such, the article examines Israeli modernity in 
three trajectories: economic realm (economic development), political realm (democratization) and social realm (secularization). As the main aim of the work is to propound and prove the argument that Israel is a non-Western society via developing a non-Western modernization perspective, a comparative research approach constitutes the major axis of the methodology of the article based on qualitative analysis. Comparison and contrast between Israeli and Western types of modernities will be offered throughout the article to construct a satisfactory and persuasive framework about the nature of Israeli non-Western modernity, supporting it with statistical data such as indicators of economic growth obtained from primary sources.

\section{Theoretical Framework: Modernization Studies and Eurocentrism}

Modernization purporting to be an unprecedented supremacy of the West - especially in military - in the $18^{\text {th }}$ century has come to be the most stunning and striking phenomenon for societies across the world. Thus, an intellectual initiative called "modernization studies" has arisen in diverse fields ranging from economics and sociology to political science. Beginning with the de-colonization efforts both before and after World War II, such studies have dramatically intensified with the undeniable influence of America's hegemonic rise after World War II. Within the existing literature, the dominance of the so-called Classical Modernization Theory (CMT) in the 1950s and 1960s has been challenged by non-Western perspectives such as the Multiple Modernities Paradigm (MMP) and the nascent Uneven and Combined Development Theory (U\&CD) (Göksel 2016; Göksel 2018a).

Firstly, to understand modernization theories better, one needs to shed light on "the idea of progress" which is immanent in, and whose impact is enormous in almost all modernization theories. As a cornerstone of modernization theories, its philosophical roots could be found in Auguste Comte's positivism. Ongoing debates within the social theory of Western thinking with the mixture of functionalism and progressivism has been on the new track after WWII. Possibilities of a stable change of societies as a subject matter have been on the agenda of social theorists especially since the 1950s. Elucidating the nature of an industrial society, it was claimed - especially by CMT - that modern societies have been converging towards a common and ineluctable destination created by the technical and organizational consequences of industrialization (Hawthorn 1987: 242).

Blending the idea of progress with structuralism/functionalism, Talcott Parsons, an American sociologist was the key practitioner in producing a general theory of social action after WWII (Altun 2002: 98-99; Preston 1996: 171). As a classical representative of the progressivism of the $20^{\text {th }}$ century, he argues that societies evolve from one polar to another polar. This evolution, which is deemed to go towards the good and the better, is a perpetual phenomenon and is about the emancipation of enchained human beings. Taking the experience of Western societies, in particular the American society, as an embodiment of modern society, he claims that Reformation, Renaissance and various revolutions taking place in the $18^{\text {th }}$ and $19^{\text {th }}$ century Europe were not spontaneous events but steps taken by Western societies towards the predestined target, a modern society (Erkilet 2007: 113-119; Altun 2002: 98-110). Given Parsons's incontestable influence on later modernization scholars, all these theoretical assumptions have shaped the general framework of modernization theories although they have faced some major criticisms since then. Namely, 
the idea of progress brought modernity into force, and thus interconnected the fate of different societies as its advocates believe that the others will complete the stages of modernity specified by the West.

What is commonly agreed on by modernization theorists in the body of classical scholarly literature is that modernization is a sort of "social change" which is both transformational in its impact and progressive in its effects. Viewing it as extensive in scope, they tend to regard it as a "multifaceted process" (Tipps 1973: 202). Although there are other pillars or dimensions like individual or cultural, the point CMT scholars arrive at a consensus is that extensive impacts of modernization trajectory have been observed as profound changes and developments since the Industrial Revolution in the $18^{\text {th }}$ century in three interrelated and vital veins of a society: social, political and economic (He 2017: 184; Huntington 1968; Lerner 1958). Developments or changes in economic trajectory contain an "industrialized", "market-based", and "specialized" formation of economy, which will bring other changes such as "urbanization"; in the social trajectory, it nurtures a "secularized", "traditional valuefree", and "rationalized" social structure; in political trajectory, it nurtures a "centralized" and "bureaucratic" state formation having a "liberal democratic regime" and "rule of law" (He 2017: 186).

CMT, to put it simply, regards a society having embodied "industrialization", "secularization" and "democratization" processes as modern (Göksel 2015: 76-77). It is quite fair to argue that the most striking assumption of CMT is its emphasis on the supposition that there is a positive correlation between these three processes. CMT scholars such as Seymour M. Lipset, Barrington Moore and Daniel Lerner argue that any increase of economic development promotes, encourages and reinforces the increase in the level of democracy by predicating their arguments on several comparative analyses in the non-Western world. In other words, socioeconomic development and level of democracy of a society are positively related (Arat 1988: 21-23; Göksel 2015: 74-75). Logical deduction of this, "positive feedback loop" called by CMT, stems mainly from the question of why most economically undeveloped societies are - or have been - ruled by authoritarian regimes whereas most of the economically developed are - or have been - governed by democratic regimes.

Transition of societies to new stages or phases of modernity, which could be carried out mainly by dynamics that modernization trajectory has brought along, is a common argument all CMT scholars share. Although there are some different denotations of these successive stages within the classical doctrine, essentially, a society goes through from "traditional" one, which is a great obstacle to rationality, secularization and thus modernity, to a "modern" one. Considering this transitional society model as universally applicable makes possible the assumption that every traditional society which could be observed most concretely in the non-Western world, and which seeks to be modern, is progressing towards a modern one, and that this process is irresistible and irreversible once a society begins to modernize (He 2017: 187; Lerner 1958; Coşkun 1989: 301; Gusfield 1967: 1). This devaluation of "tradition" by CMT puts it in opposite of modernity, making them both irreconcilable and contradistinctive like fire and water.

As it can be seen above, CMT's deterministic character attracts the attention as it tries to specify a foreordained modernization trajectory on which all societies will converge. This deterministic character results mainly from the Eurocentrism immanent in CMT. Western 
modernity as a product of the European Enlightenment had appeared when the formation of center/periphery division of the world began to arise in intellectual orientations. In this formation the Western mind put itself at the centre and all the others at the periphery (Dussel 1990: 65). That discloses an implicit illusion constituting one of the basic components of Western modernity. One of the main reasons for the constitution of this illusion is a great shift in the Western thought to logocentric epistemology formulated by anthropocentric understanding of existence, which had come to fruition after the shift from the God-centred theological understanding of the universe (Sunar 2016: 3-6). The critique that CMT scholars have built their assumptions on a biased and cumulative fund of knowledge about "the others", particularly the East, which has been provided by missionaries, travellers, and merchants in the $16^{\text {th }}$ and the $17^{\text {th }}$ century, is the most salient, accepted and tenable argument among critical intellectual circles (Sunar 2016: 22). This imaginary knowledge, as severely attacked by Post-Colonial studies, has paved the way for the genesis of an academic bigotry called "Eurocentrism". The incompatibilities of non-Western societies with - and their divergences from - Western modernity have been noticed in the modernization trajectories of Iran (see Matin 2013; Göksel 2019), Turkey (see Göksel 2015; Göksel 2018a), Azerbaijan (see Khalilzada 2019) and numerous Asian societies. Collectively these divergent nonWestern modernization experiences have highlighted the Eurocentric bigotry and theoretical insufficiencies of CMT.

The Iranian Islamic Revolution of 1979 has reversed the so-called pace of history, unilinear path of modernity, notably the secularization thesis that is immersed in classical modernization studies (Göksel 2019). Having been achieved in a highly urban and socioeconomically modern state headed by Western-oriented elites, the theocentric aspect of the revolution made it "an exception" in the eyes of Eurocentric modernization studies (Matin 2013). Remaining as a theoretical riddle, created by a peculiar polity that is neither fully authoritarian nor fully democratic, Iran has induced a re-appraisal of existing theories embodying Eurocentrism. On the other hand, the Turkish model of modernity also stands for a divergent path of non-Western modernity as it supplanted the Eurocentric suppositions of mainstream modernization theories, specifically the CMT. Although it has reached a very high level of economic development, Turkey is unable to become a liberal democracy (see Göksel 2018c) and forming a fully-fledged secular society - which stands to challenge the positive correlation pillar of CMT. Furthermore, economic development has neither reduced the lingering religiosity of Turkish society nor hindered the emergence and rise of a strong Islamist political movement in Turkey (Göksel 2015; Göksel 2016).

Taking modernity as an institutional transformation that have their origins in the West, Giddens argues that globalization, which is the foremost yield of modernity, and is seen by him as a process of uneven development cannot make modernity Western (Giddens 1990: 175). Moreover, in an attempt to overcome the problem of Eurocentrism, Kamran Matin (2013) points out four interrelated illusions from which intellectual bigotry has resulted: historical, positing the endogenous and autonomous emergence of modernity in Western Europe; normative, claiming the superiority of Europe to the rest of the world; prognostic, taking European experience as universal and universalizable through mechanisms implied by the first, historical assumption; and lastly stadial, referring to the progressive character of modernity and thus the forthcoming occurrence of the convergence of every modern society 
throughout the world. Accordingly, incarcerating all societies in an abstract universal history, Eurocentrism makes modernity a factual process that begins with and ends with Europe. This leads to an intellectual blindness that ignores distinct patterns of development occurring in the non-Western world and leads to obscureness of theoretical thinking of CMT when construing them as anomalous exceptions (Matin 2013: 2).

\section{A Non-Western Modernization Perspective}

Given the rising dissatisfactions with mainstream modernization theories such as CMT, the importance of studying modernizing societies through non-Western lenses has recently come to the forefront. Starting with MMP in the 1990s, endeavours to assess the different paths of modernization in a new non-Western theorizing keep up recently as reinforced by the U\&CD theory as well. Being an attempt to decentralize the hegemonic place of Western modernity in modernization studies, "non-Western" does not refer to unmodern or anti-West societies. It, however, is an initiative to scrutinize again the changing experience of, and the definitions of, modernity including concepts such as multiple-modernity, alternative modernity and local modernity (Göle 2007). Need for re-reading these societies is closely pertinent to a hybrid and eclectic social formation stimulated by their own dynamics given waning ties of modernity/modernization with the Western experience. With the purpose of supplanting a monotype, unilinear trajectory of modernity, and with inspirations from MMP and U\&CD, non-Western modernity undertakes to bring the analyses of local facts in universal discourse (Yücedağ 2010).

For all intents and purposes, the non-Western modernization perspective bestows a theoretical resistance to the popularized norms of analysis that are anchored both in Western discourse and in the mainstream scholarly literature, rejecting pluralistic and multicivilizational hallmarks of modernity. It aims at decentralizing romanticized conceptualizations of Western modernity by rereading the non-Western civilizations or cultures diverging from Western trajectory. It, however, does not aim to erode the concept of modernity, leading to its self-erosion amounting to loss in the meaning (Göle 2000: 91-92). The premise that the Western pattern of modernity is the only authenticity of modernity has been challenged from within Europe itself ideologically: Soviet Union as communist and Germany as fascist/national socialist type. Taking this fact into consideration as well as divergent non-Western patterns, the non-Western perspective may be considered as an attempt to deconstruct the idea of the "convergence of all societies" presumed by CMT and uttered by the globalization discourse. Accordingly, above all, the foci point is to supplant Western monopoly on modernity (Eisenstadt 2000).

Intellectual efforts called the Multiple Modernities Paradigm (MMP), in a way, came up with a challenge to the above argumentation put forward Western monopoly on modernity/modernization by "de-westernizing" this settled reasoning in CMT. Not only structural differentiation in various institutions in non-Western societies, like in education, mass communization etc., but also the ways in these areas were defined, organized and varied greatly. Different patterns influenced by cultural premises, traditions and historical experiences of these societies can be seen easily although many have taken Western modernity as a model country (Eisenstandt 2000: 1-3). On the other hand, although the rapid 
rise of non-Western societies as a new model of modernity pulled the attention towards a new path of modernity, Wittrock argues that modernity has been "multiple" from the very beginning as is seen in different patterns within Europe itself (Wittrock 2002; see also Eisenstandt 2000).

MMP is one of the main opponents to the convergence thesis standing for the predictive argument that all modernizing and developing nations/societies will have the same societal pattern as they proceed from the beginning stage of industrialization to highly industrialized nations, which is economically capitalist; socially secular; and politically the one having liberal democracy, as highly affected by Talcott Parsons's unilinear path theorization. As is understood by MMP's definition of modernity as a "story of continual constitution and reconstitution of a multiplicity of cultural programs" (Eisenstadt 2000: 2), since modernity is contingent on culture, to claim the plural character of modernity/modernization is reasonable and necessary. For them, if modernity is taken as "an open-ended horizon in which there are spaces for multiple interpretations", the illusion of supposed final integration, totalizing, Eurocentric bigotry in modernization theories could be overcome, thus making room for different features of non-Western cultures by new interpretive approaches to modernization (Kaya 2004a; Kaya 2004b). In other words, we are very likely to see diversified, distinct cultural meanings and programs on the way to modernization in line with their capability to interpret the basic symbolic conceptions and legacies they inherit from their pre-modern, axial past (Preyer and Gerald 2016: 59).

Last but not least, the MMP scholars, regarding it as a reflection of the Eurocentric bigotry, argue that the deduction of positive feedback is solely based on distinct experience of the Western societies/states. Taking Russian, Chinese and Singaporean modernizations which are under authoritarian rule despite high industrialization and mechanization as examples, MMP claims that there may be negative or even no feedback between democratization and modernization. Furthermore, in theory, a leader or ruling party of a country may spend budget of the country to win upcoming elections again, being in the pursuit of own selfinterests thus preventing economy from growing (Göksel 2016: 251-52). In other words, for MMP, modernization that started in a society does not necessarily bring with secularization or democratization in that society (Göksel 2015: 85-86).

In addition to MMP, another challenge has come from the newly-emerging U\&CD theory whose theoretical roots can be found in Bolshevik politician and theorist Leon Trotsky's works in which he analysed modern capitalist development (Matin 2007: 428). Recently, scholars such Kamran Matin, Kerem Nisancioglu and Alexander Anievas have tried to develop and apply U\&CD theory to various fields ranging from international relations, historical sociology to modernization studies. To understand U\&CD theory better, it is necessary to dwell on four interrelated concepts upon which the basic assumptions of the theory is built in parallel with a modernization perspective; the whip of external necessity, substitution, historical reshuffling and the privilege of backwardness (Matin 2013: 17-18; Göksel 2018a: 69-71).

Putting emphasis on influences derived from external actors, the whip of external necessity refers, in terms of modernization studies, to the idea that the struggle for survival, for a backward society, is the main trigger to embark on modernization. This is acceptable especially as one thinks of it in historical context. The imperialist/expansionist politics of 
France, Britain etc. has played a great role in triggering the intensive modernization initiatives of the Ottoman Empire in the late $19^{\text {th }}$ and the early $20^{\text {th }}$ century along with the instinct of self-defense, for example (Göksel 2015: 96; Göksel 2018a: 70-71). For U\&CD theory, it is quite plausible to argue that the impact of foreign ideas and products on a modernizing society are highly influential. In this sense, being a natural and conjecturable outcome of the whip of external necessity, substitution refers to the unpredictability of this impact of the flow of these ideas and products upon that society. In other words, the external driving force of the more advanced as prototype, for the less advanced, is a persuasive reasoning for $\mathrm{U} \& \mathrm{CD}$ theory. Thus, the mix of domestic and foreign elements brought by modernization leads to the subversion of way of modernization of that society trying to imitate the prototype (Göksel 2015: 97; Göksel 2018a: 69-71). This, for Matin, makes possible to chart a variety of apparently paradoxical patterns of development and political strategies in non-Western cases (Matin 2013: 17).

The inclusion of foreign elements into the social, economic and political life of a society induces the reactive motivation of that society while adopting them. Being closely linked to the phenomenon of "substitution" and called "historical reshuffling", this reaction to, or interaction between domestic and foreign components results in the divergence of historical process of a model country in less-developed - namely - non-Western societies. The historical reshuffling has dynamics to create a divergent path of modernization in nonWestern societies, and thereof is to supplant convergence thesis resulting from CMT's ignorance of the explicit role of international context. According to Matin, backwardness is a privilege as the backward societies have the capacity and opportunity to skip all previous stages or experiences through which the developed/prototype societies had passed (Matin 2013: 19; Göksel 2015: 97-98).

Although all theories agree on the inference that drastic changes brought by modernity/modernization occurs mainly in the three pillars of a society -political, social and economic pillar, whether there is positive correlation between them is controversial. As the recent divergent modernization trajectories of non-Western societies such as Turkey, Iran and Azerbaijan (Matin 2013; Göksel 2016; Göksel 2018a; Khalilzada 2019) have shown the inconsistency of CMT whose Eurocentric approach obscures its theoretical inquiry about modernization process in the non-Western world, MMP and U\&CD have proven successful in revealing the ill-thought of CMT by drawing all attention towards divergence of societies rather than the convergence argument corroborated by the idea of progress of Western social theory. In this sense, the non-Western modernization perspective offers a wide-angle lens by taking historical contingency and international context into consideration with the help of inspiration from MMP and U\&CD while evaluating many Western and non-Western modernization trajectories within their unique circumstances.

\section{The Israeli Non-Western Modernity: Historical Overview and Contemporary Nature}

While CMT takes modernity as an organic process in which social forces play the key role in initiating and promoting the process, U\&CD theory argues that modernization is triggered by inorganic factors such as survival instinct, taking international context into consideration. An "organic" character draws attention in the historical origins of Western trajectory - Britain, 
France and the United States of America - vis-à-vis that of Israeli experience. Namely, as Barrington Moore showed properly, a domestic social force, "strong urban bourgeoisie" has been the primary actor in initiating and promoting developmental trajectories in the West (Moore 1966). On the other hand, the basic principle of the U\&CD, "whip of external necessity", could be seen easily in Jewish historical experience in the eastern and central Europe, paving a way for the establishment of modern Israeli state. The Jewish Question, which began to emerge in the $19^{\text {th }}$ century and to appear more visibly after various pogroms and Nazi's tragic Holocaust against the Jews living across Europe in the late $19^{\text {th }}$ and early $20^{\text {th }}$ century, was a triggering factor in the sense of a survival instinct as demonstrated by the $\mathrm{U} \& \mathrm{CD}$ theory.

In terms of the whip of external necessity, the Jewish encounters with modern Western civilization accounts for an external source as the origin of later Israeli modernization. The interaction between them appeared in the form of successive pogroms in the late $19^{\text {th }}$ and early $20^{\text {th }}$ century and the subsequent Nazi Holocaust against the European, especially eastern European Jewry. The destructive and brutal encounter with the Western civilization hereby resulted in, among the European Jews, an awareness that having a safe homeland is critical for gaining and preserving the full emancipation of Jews (Laqueur 1972: 590). Rising antiSemitism, nourished by all the pogroms, the Holocaust and persecutions taking place in Europe, stimulated the Zionist movement, whose primary aim had been to establish a Jewish National Home wherein the oppressed and downtrodden world Jewry could live within wealth and safety. Having been driven by such a survival instinct, Zionist leaders found a definite solution to the plight of European Jews in the establishment of a modern state in the Palestinian lands. Conducting massive and successive migrations, the Aliyah, to the land of Palestine, and creating proto-institutions and an infrastructure for the prospective modern Jewish society, the Zionist movement attained its own dynamics to have a modern state mainly from the successive pogroms and the Holocaust against the Jews in Europe. survival instinct, emerged from the encounter with the West, has had drastic consequences on Israel modernization trajectories, especially on economic trajectory.

\section{Israeli Economic Modernization: A Divergent Historical Trajectory}

As the Zionist-labour wing within the Zionism movement was the dominant actor in the prestate Jewish community, the main driving ideology for economic activity was the "conquest of labour" strategy and economic collectivism based on agricultural production. Small collective agricultural organizations such as Kibbutz and Moshav have been established to promote economic activities. On the other hand, the Histadrut (the General Organization of Workers), more than a trade union, functioned as a quasi-state organization where there was no strong bourgeoisie capitalist class due to the collectivist economy of agrarian Jewish community. Such a collectivist economic complex has remained several decades after the statehood, becoming the main force that diverges the Israeli economic trajectory from that of the Western capitalist development. The Israeli state-led economic modernization was restrained through many liberal reforms in the economy after the mid-1980s onwards. 
However, the institutional framework tracing back to the pre-state era has had impact on the subsequent economic modernization in Israeli trajectory.

As emphasized above, the trigger for Israeli modernization in sense of the whip of external necessity of Uneven and Combined Development (U\&CD) was pogroms and subsequent Nazi Holocaust against European Jewry. The Zionist movement managed to turn these persecutions into a nation building project in Palestine. It is obvious that this "whip" has continued under the discourse of "national annihilation" as it has been manifested in several wars and conflicts with Arab states and thus it has left a lingering impact on Israeli society. The Arab states' challenge to Israel's existence triggered and kept up the economic modernization in Israel as the wars and conflicts with Arab states were inclined to becoming endemic.

Arab states answered to the declaration of a Jewish state in Palestine in 1948 with a war declaration against Israel. The war in 1948 and the subsequent armed conflicts in 1967 and 1973 have made the dispute between the Arabs and Israel chronic The disputes and tensions, which became perpetual over the years, were regarded by the Israelis as a threat to their national unity. So, a national annihilation discourse, which had already manifested after pogroms and Holocaust in the eyes of the Zionist movement, has proved to be true in the eyes of the entire Israeli society. In this sense, as a survival instinct, the threat manifested in wars and conflicts with the Arab states urged Israel to be an economically powerful state. Otherwise, it would be unreasonable to think of an economically weak Israel confronting the threat to its existence. In sum, a survival instinct has stimulated Israeli economic development, thus modernization, after the establishment of the Israeli state in 1948 as well as in the era before the statehood.

Survival instinct has played a key role in initiating both the massive industrialization policy from the 1950s onwards and the emergence of a military-industrial complex from the mid-1960s onwards. As illustrated above, the economic boom from the mid-1950s onwards has resulted mainly from the state-led development based on a massive industrialization (see Ben-Porath 1986). Furthermore, the most concrete manifestation of survival instinct can be seen in Israeli economic development based on military-industrial complex after the mid1960s. Although the surface cause in the emergence of the Israeli military industrial complex could be attributed to France's embargo on arms sale to Israel after the 1967 War, the latent whip was the survival instinct as manifested in the national annihilation discourse (Mintz 1983). In a nutshell, as Arab states impose existential threats to Israeli society, Israeli economic modernization is in keeping with the argument, the "whip of external necessity" of the U\&CD theory that modernization projects are triggered by a survival instinct.

In the Israeli case, directly shaped by the socialist ideas of the labour wing within the Zionist movement, quasi-state institutions and organizations, which were established in the pre-state era and have existed from the early 1920s onwards, set Israeli economic trajectory apart from the Western model as a "historical reshuffling" manifested. The Histadrut, as the largest trade union whose functions and capacities went beyond that of an ordinary trade union, has been the leading economic actor in performing the central functions of economic development by creating an organizational complex in which a small state-dependent bourgeoisie class exists. Supported economically by various governments and the state apparatus, it has owned largest companies and conglomerates in various sectors of the 
economy ranging from agriculture, industry to finance. As a distinct form of economic development, it acted as a quasi-state organization by shaping the formation and the accumulation of the capital, as well as functioning as one of the largest employers in the country where an indigenous strong capitalist class did not emerge (Grinberg 1991; Grinberg 2017; Shalev 1992).

Economic - also political - dominance of the Histadrut did not wane after statehood. This continued dominance has led to complex networks in the relationship between state and quasi-state institutions. As a distinct pattern called "split corporatism" from that of Western type development, some peculiarities occurred within this complex pattern. Split corporatism refers to the combination of "dual market labour" in which the labour class is weak while the capital class is strong, and "corporatism" in which capital class is weak, and the labour class is strong. As the former is more associated with the free-market economic model of the West, it is likely to see its most concrete example in the United States of America. As the latter can be defined easily as "state-capital cooperation", Sweden is seen as its classical example for a compromise between capital, labour and state. On the other hand, as Lev Grinberg argues, it is split corporatism that typifies Israel as a distinct pattern in which both capital and labour are relatively weak in private sector based on state subsidies whereas the both are strong in the public sector (Grinberg 1991). Four peculiar characteristics must be noted in this context: (1) the pivotal role played by the Histadrut as a quasi-state, an employer and a trade union; (2) extensive state involvement in economy and thus precedence of large public sector; (3) weak private capital dependent on state subsidies; (4) split labour force between strong public sector employees and weak industrial workers (Grinberg 1991: 61-62). Although this distinct pattern began to fade after the massive liberalization process in the 1990s, the state-led economic development was almost wholly handed over to the private capitalists who have dominated the economy. This pattern has diverged the Israeli trajectory from that of the West. So, substitution (split corporatism) manifests in Israeli economic modernity as an unpredictable result of historical reshuffling - the Histadrut and the other quasi-state institutions (see Table 1).

Table 1. U\&CD Theory and the Economic Trajectory of Israeli Modernity

\begin{tabular}{|c|c|}
\hline $\begin{array}{c}\text { Whip of external necessity } \\
\text { [Triggering factor] }\end{array}$ & $\circ \begin{array}{l}\text { National annihilation discourse produced } \\
\text { reinforcingly by wars with Arab states }\end{array}$ \\
\hline Historical reshuffling & $\circ \begin{array}{l}\text { Quasi-state organizations (e.g. The Histadrut) } \\
\text { shaped by the socialist collectivism of Labour } \\
\text { Zionism }\end{array}$ \\
\hline
\end{tabular}




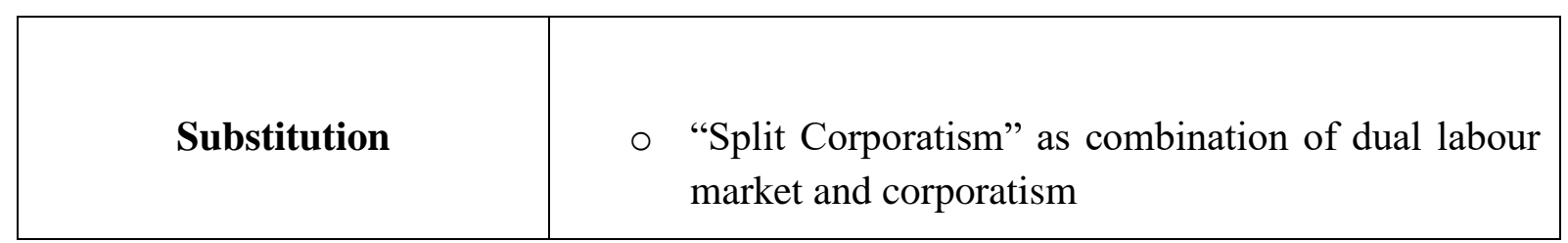

Source: Author based on the U\&CD model of Göksel (2018a: 72).

The fact that there were hardly any private enterprises namely a capitalist class and that instead there was an all-powerful organized labour - The Histadrut - performing state functions such as public sector enterprises, pension and healthcare is an outstanding feature of the Israeli economic modernity diverging from the historical path of free-market model in which a strong capitalist class had played the key role, being the first driving force in initiating economic modernization (Moore 1966; Hanieh 2003). While the power of the organized labour has been diminished over years, the primary actor in economic modernization has been the state not private sector. Restricted share of private sector in economic modernization, bourgeoning of relatively more independent private initiatives and thus capitalist class showed up only in the 1990s. Today, the Israeli society possesses many manifestations of an economically modern state, ranging from high urbanization; industrialization and GNI per capita to low share of agriculture in the economy (see Table 2). In regards with this, Israel can be evaluated as an economically modern state by CMT as well as by MMP's definition of economic modernity whose main indicators are industrialisation, urbanization, a centralised economic management structure, high literacy etc. (see Eisenstadt 2000; Wagner 2012; Arnason 2000).

Table 2. Israel's Economic Development Indicators (2016)

\begin{tabular}{|l|l|l|}
\hline Indicators & On the basis of & Rate \\
\hline GDP & billion \$ & 317.748 \\
\hline Industry & $\%$ of GDP & 20,8 \\
\hline Agriculture & $\%$ of GDP & 1,3 \\
\hline Service sector & $\%$ of GDP & 77,8 \\
\hline GNI per capita & $\$$ & 36,258 \\
\hline Urban population & $\%$ of total pop. & 92,2 \\
\hline Life expectancy & Year at birth & 82,05 \\
\hline Individual internet usage & $\%$ of total pop. & 79,7 \\
\hline
\end{tabular}

Source: World Bank (2018). 
In sum, a distinct pattern in Israeli economic trajectory can be seen via the lenses of the U\&CD theory (see Table 2). In this sense, a national annihilation discourse which has been persistently reinforced by a sequence of wars with Arab states, accounts for the whip of external necessity. As the process in economic trajectory has been launched by this whip, "historical reshuffling" manifests when the dominant position of the Histadrut acting as quasi-state in the pre-state era continued in the post-statehood period within a state-led economic trajectory until the mid of 1980s when many reforms were made for the liberalization of the economy. Accordingly, historical reshuffling has sparked off the emergence of substitution, a complex power relationship of economic actors, which can be conceptualized as split corporatism. On the other hand, Israel today has achieved a high economic growth with high urbanization and industrialization and can be evaluated as an economically modern state. Yet, a positive correlation between other trajectories, the political and social, did not emerge as CMT presumes that a high economic development would inevitably result in a liberal democracy and a high secular society. The following section of the article discusses this in detail.

\section{The Political Trajectory of Israel: Illiberal Democracy without Bourgeoisie}

CMT scholars equate political modernization with democratization, meaning that a modern society will always end up with the establishment of a liberal democracy. On the other hand, MMP perceives a politically modern society as one having a centralized and effective decision-making mechanism. Democratic governance let alone a liberal type may not be a foregone conclusion at the ultimate stage in non-Western countries (Wagner 2012; Arnason 2003).

The Israeli political modernization has clearly showed a divergent democratization trajectory within its own historical context. Although the Israeli state was established as a democratic polity in 1948, having a liberal democratic polity has never been an aspect of Israeli democratization. Jewish community in the pre-state period had a self-government without absolute sovereignty, which allowed them to spread the seeds of the forthcoming political modernization. Led by the elites of labour Zionism, most of whom were eastern European Jews impressed by socialist ideas, collectivist movements hampered the emergence of a strong or even petit bourgeoisie in the pre-state Jewish self-government (Shapiro 1984: Eliezer 1993: 399-400; Neuberger 1990). Since the labour movement got even stronger after the statehood by remaining in power until 1977, the emergence of a flourishing and fullfledged capitalist class became only possible by privatization and liberalization attempts after the mid-1980s. As such, select elites, the Zionist Labour politicians, have become the primary actors in initiating and maintaining political modernization in Israel where there were not any social forces such as a capitalist bourgeoisie class or a robust civil society. In other words, a petty bourgeois as a social force as in the Western trajectory emerged in the country only after the economic and social infrastructure had already been put in place by the socialists/collectivist Zionist elites of the labour movement. This Israeli divergent pattern, "democracy without bourgeoisie", contradicts with the emergence of democracy in the Western trajectory (France, Britain, the USA) where strong capitalist class - the bourgeoisie 
- has played the primary role in forming and promoting democratic regime and, thus started the political modernization in the West (see Moore 1966).

The end of labour hegemony in Israeli politics could not stop the consolidation of Israel's non-liberal democratic trajectory. A number of shortcomings, ranging from troubled religion-state and civil-military relations to the exclusion of non-Jewish citizens, has been undermining the liberal democratic trajectory in Israel. As the constitution occupies a higher place than ordinary laws within a legal system, having a constitution is the prerequisite in qualifying and protecting non-procedural criteria of liberal democracies such as basic rights and liberties based on human dignity within a country. Israel has been unable to draw up a written constitution due to the disagreement on the principles of Israeli political system since its foundation (Lerner 2004: 239; Sen 2015: 108). Having been in a very vulnerable legal basis, right to freedom, for example, have not been guaranteed by a constitutional arrangement. Rather, it is substituted by some legal arrangements called "Basic Laws", which can be amended and enacted by a simple majority in the parliament. Comprising a basis for the exclusion of non-Jewish, not least the Arabs, it is the social discourse of citizenship that introduces Jewish ethnicity as mandatory to be a party of the community in which one's status is determined in accordance with his contribution to common good. Thus, the exception of Arabs from military service, regarded as a vital contribution to common good, puts them in a lower social status than Jewish citizens. On the other hand, the fact that great numbers of social rights are conditional upon the fulfilment of service in the military makes the exclusion more severe (Ben-Porat 2011: 206-207). The root of socio-political exclusion stems from the self-contradictory definition implicit in the Declaration of the Independence that proclaimed "complete equality of social and political rights without distinction of creed, race or sex", and Israel as "the state of the Jewish people".

As it will be emphasized in the following sections on Israel's secularization, the permanent coalition based on mutual interests and consociational principle between the orthodox religious camp and political authority has maintained together the rising political power of Jewish fundamentalist parties. Having been the cardinal guardian of the religious status quo, the orthodox camp has held the balance of power in the Knesset throughout the Israeli political history (Yiftachel 1999: 378). Embodied in the non-liberal character of Israeli democracy, the tenor did not change in the current Israeli political landscape. Although the Supreme Court interfered in some issues, the religion-state relations, dominated by the former and contrived in the early of the post-statehood period, has been upheld so far (Lerner 2013: 624).

Lasting military conflict with the Arab states has had remarkable consequences on Israeli liberal democracy. There have been no legal and regulatory mechanisms to constitute a strong civilian authority independent of the control of the IDF (Israel Defence Force) (Peri 1983: 147-148; Etzioni-Halevy 1996: 405). The vague demarcations between Israeli political and security establishments have been manipulated easily and frequently (Schiff 1992: 646). This makes the relations both troubled and fragile in the context of democratization, being unable to preclude insubordination and indirect intervention of military elites to political arena. The fact that there have not been any coup attempts and great disputes between the civil and military wings does not mean that the military would not jeopardize the liberal democratic consolidation of Israel. Dominated by the latter, the relations between civil and 
military authorities have continued in favour of security networks, especially the IDF, in peace times, which demonstrates overriding power and influence of the latter upon vital decision-making process. Security network at times has become more powerful than a political party in influencing major parties in an attempt to change the government's policies (Sheffer and Barak 2013: 100-101). This kind of civil-military pattern, therefore, has had negative reflections on Israeli democracy, revealing its divergence from the Western/liberal democracy model.

Rather than a liberal democracy, Israel can be defined more accurately as a "majoritarian ethnic democracy" which refers to the institutionalization of the dominance of one ethnic group (Jews) over others (see Smooha 1992; 1990; 2002), or it can be defined as a procedural democracy since it properly and regularly fulfils procedural requisites of democracy such as holding regular elections and giving citizens right to vote rather than explicitly warranting fundamental freedoms. An uneven pattern manifests with factors undermining liberal democracy in Israeli political modernization from the perspective of the U\&CD theory (see Table 3). Triggering factor in the form of whip of external necessity is again a lingering survival instinct, which constitutes a background for the entire Israeli modernization. Historical reshuffling can be observed in the initial democratization led and conducted by a political elite affiliated with Zionism where there were no organic social forces such as a robust capitalist class, bourgeoisie, or civil society that could push it in favour of liberal democracy. As an unexpected outcome, substitution refers to a divergent model of democracy called "ethnic democracy" whose legal basis is constituted by the recently-enacted Basic Law, the so-called "Jewish Nation-State Bill”, in July 2018.

Table 3. The U\&CD theory and Israeli Democratization

\begin{tabular}{|c|c|c|}
\hline $\begin{array}{c}\text { The whip of external } \\
\text { necessity }\end{array}$ & o & Survival instinct \\
\hline Historical reshuffling & $\begin{array}{l}0 \\
0\end{array}$ & $\begin{array}{l}\text { A political modernization led by Zionist elite } \\
\text { Democracy without bourgeoisie }\end{array}$ \\
\hline Substitution & $\begin{array}{l}0 \\
0\end{array}$ & $\begin{array}{l}\text { Ethnic democracy as domination of an ethnic group (Jews) } \\
\text { over others } \\
\text { "Jewish State" enshrined by Nation-State Bill recently enacted } \\
\text { by the Knesset in } 2018\end{array}$ \\
\hline
\end{tabular}

Source: Author based on the U\&CD model of Göksel (2018a: 76).

It is not possible to place Israeli democratization in the category of politically modern societies through the lenses of CMT since it does not conform to a formation of liberal 
democracy within its own historical trajectory. Yet, showing a divergent pattern from the Western trajectory, Israel can be regarded as politically modern through the lenses of MMP given the fact that it has been holding centralized and effective decision-making mechanisms since its establishment in 1948. Referring to the supposition that economic modernization would result in the emergence and consolidation of a liberal democracy in the political trajectory of modernity, CMT's argument of "positive feedback loop" between the economic growth and democratization is unable to account for the nature of the Israeli case. As is clearly shown above, Israel can be regarded as an economically modern state not only by MMP but also by CMT. However, today Israel's unconsolidated liberal democracy fairly falsify CMT's hypothesis based on the convergence of modernities. On the other side, arguing mainly that modernization occurs in multiple and various forms or ways between and within different societies, MMP and U\&CD relatively provide more tenable framework in Israeli case through non-Eurocentric/non-Western lenses. So, the globalization discourse is in contradiction with the Israeli political trajectory as well as CMT, namely modernization - the combination of social, political and economic changes - does not necessarily lead to democratization in a country.

\section{The Social Trajectory of Israel: Unguarded Secularization and Lingering Religiosity}

Israeli social modernization experience stands out as the most distinct trajectory that radically departs from the Western modernity. As emphasized above, CMT presumes the wane of religion and religious authorities in a socially modern society in the form of a secularization process, which is positively and considerably affected by other trajectories, namely by economic development and democratization. As such, the ascendance of a religion either in the form of religiously oriented political parties or social movements are not seen to be likely in modern societies as traditional and religious ethos are supposedly replaced by modern ones. One of the factors giving way for the wane of religion in a modern society, for CMT, is high economic development.

Established and influential religious authority has never ceased to exist in Israeli secularization. Unlike the Western social trajectory based on secularization, which has been initiated from within and driven organically, the Israeli state was founded as secular by the Zionist political elite, displaying its top-down character. Constituting the origins of the current domination of the religion in economically modern Israel, the "Status-Quo Agreement" signed in 1947 between the orthodox religious camp and Zionist political elites, has become the main determining factor in Israeli social trajectory. Concessions given to the religious authority (The Chief Rabbinate) in the agreement prevail even today, including (1) the embracement of Saturday, which is called Sabbath and considered as holy day in Judaism as a day of official rest and prohibition of shopping and public services on this day; (2) applying the Jewish dietary rules (Kosher food) in all public institutions; (3) giving jurisdiction to Orthodox rabbinate and rabbinical courts over marital and burial issues; (4) religious education in public schools and autonomy for ultra-Orthodox schools (Yeshiva) and accordingly exemption of Yeshiva students from military service (Rubinstein 1967: 113; Fox and Rynhold 2008: 510; Tepe 2008: 85). 
On the other hand, institutional (non-political) and political authority (fundamentalist political parties) in Israel are intertwined. Whereas the Chief Rabbinate has been holding a determining role over The Mafdal's policies, the Council of Torah Sages holds ultimate authority over the Shas Party. There is a relationship based on mutual interests, meaning that political leaders are dependent on the appeal of religious authority in electoral campaigns whereas religious leaders are dependent on political parties in taking religious compromises from secular authority (Hazan 1999: 170). The political power of the fundamentalist parties, due to Israeli parliamentary system forcing the secular parties to form a coalition with them, makes the established religious authority one of the main actors in Israeli politics (Kimmerling 1999: 352). As such, their survival and untamed status in all governmental coalitions remark this fact, making, in political arena, their bloc a vanguard and guarantor of the religious status quo founded in the pre-state period, and impeding the secularization trajectory of Israeli modernity.

The interconnected texture between religious identity and ethnic/national identity in Judaism constrains the non-religious and the secular from adopting marginal and pro-active attitude towards religious status quo (Ram 2008: 65-66). The most concrete manifestation of this can be seen in the non-secular-nationalist definition of the Citizenship Law in I952. The law in question sets the criteria for citizenship in a non-secular-nationalist and ultra-religious way by giving citizenship to a person who is born of a Jewish mother, or who has converted to Judaism, and who is not from another religion (Ben-Porat 2013: 33). As well as the selfreinforcing character of the religion and in parallel with this, what cemented the position of the religion in Israeli society have been the instrumental roles it has played in the conflicts with Arab states, especially after 1967. The messianic/religious belief, "promised land", of Judaism provided the Israeli government with the rationale that occupied lands are a blessing from the God thus their natural right (Ottolenghi 2002: 47). Another instrumental role is religious legitimation for national identity towards rising Arab population after the occupation. Namely, the religion had to be on stage both for the exclusion of Arabs and for the legitimation of the newly occupied lands (Ram 2008: 66-70).

Contemporary Israeli experience has refuted CMT's prediction that is based on the inevitability of secularization in a social modernization experience. Although the State of Israel was not established as a theocratic state, it has never embarked on a far-reaching secularization program. As such, one cannot see strong and uncompromising secular elites, groups or political parties who can challenge the religious status quo. Although several secular attempts were introduced in the 1990s and a partial flexibility occurred in some religious arrangements regarding civil marriage and burial, allowing of shopping on Sabbath (Saturday) and of selling pork, these did not come from organic forces of the society but individual attempts of immigrants from the countries of former Soviet Union and thus they have been far from being a strong secular challenge to the religious status quo (Ben-Porat 2013). The religiosity of the society has remained lingering, and the religion has been occupying a remarkable place in the public sphere since the establishment of the state although Israel has achieved a high economic growth over the years. More importantly, it has a jurisdiction based on the Jewish law over personal status through the rabbinical courts. CMT falls short of expounding the survival and ascendance of religious political parties who 
have had a highly fundamentalist agenda and have become power brokers in Israeli politics by safeguarding the religious status quo established in 1947.

On the other hand, MMP envisages a flexible social modernity that does not necessarily result in a secular society. For MMP, secularization on the way of social development is not a requisite for modernization as it does not presume a positive feedback between social, economic and political trajectories. In this sense, since Israel reveals the characteristics of an economically modern state, it could be classified by MMP as a modern state even if it could not attain a highly secular society in which religion almost ceased to exist. So, the Israeli trajectory diverges from that of the West where the social development, secularization, has taken place in parallel with the economic development.

Beyond CMT, as well as MMP, U\&CD could be utilized to assess the Israeli social trajectory consistently and convincingly (see Table 4). In the sense of conforming to Western modernity, Zionism began to challenge the religious ethos of the Jews in the early $19^{\text {th }}$ century even though it did not refuse some messianic beliefs totally such as the myth of "returning to the ancestral homeland". But as a type of historical reshuffling, the natural bond between nation and religion in Jewishness was a major hindrance to the organic emergence of a secular movement among the Jews. As such, in 1947, just before the establishment of the State of Israel, many concessions were given to the religious authority in an unofficial agreement (the Status Quo Agreement) between Zionist founding fathers and the orthodox religious camp. The Status Quo arrangements were crucial in the sense that they have come to underpin the lingering religiosity of Jewish people and helping the religion not to wane in the public sphere. The establishment of Rabbinical Courts, which have jurisdiction over personal status based on the Jewish law, and of the Chief Rabbinate, which is the ultimate religious authority on all religious matters, are unexpected outcomes emerging out of the divergent path of Israeli social modernity. Deeply tied to the unwavering status of the religion, which mainly stems from the inextricable nexus between Jewish religion and Jewish nation, an unprecedented influence of ultra-religious political parties in Israeli politics could also be classified as substitution in the Israeli trajectory (see Table 4).

Table 4. U\&CD and Israeli Social Modernity

\begin{tabular}{|c|c|}
\hline $\begin{array}{c}\text { Whip of external } \\
\text { necessity }\end{array}$ & $\circ$ Survival instinct \\
\hline Historical reshuffling & $\circ \begin{array}{l}\text { Natural bond between Jewishness as religion and } \\
\text { Jewishness as nation } \\
\end{array}$ \\
& $\circ$ Religious Status Quo concord \\
\hline
\end{tabular}




\begin{tabular}{|l|ll|}
\hline \multirow{3}{*}{ Substitution } & & \\
& $\circ$ & Rabbinical Courts and Chief Rabbinate \\
& $\circ$ & Enduring survival and ossification of (ultra) \\
& fundamentalist political parties
\end{tabular}

Source: Author based on the U\&CD model of Göksel (2018a: 78).

\section{Conclusion}

Could the unique and divergent modernization experiences of non-Western societies be the proof of a challenge to Western modernity? Could Israel be evaluated as a non-Western modernity model in contrast to the common assumption that Israel is a Western country? This article hinges on the argument that the State of Israel is not a Western country as its type of modernity has significantly diverged from the globalization thesis claiming to eventually unite all societies around Western modernity. The article has argued that this could be proven through a non-Western modernization perspective which takes inspirations from the Multiple Modernities Paradigm (MMP) and the Uneven and Combined Development Theory (U\&CD). To prove it, the article examined the case of Israel in three trajectories - economic, political (democratization) and social (secularization) - in Israel's own historical context.

Israeli economic trajectory diverges from Western economic trajectory. Israeli society today can be regarded as an economically modern society by all modernization theories as it is a highly industrialized and urbanized society with high average living standards. However, what is the most remarkable fact observed in Israeli economic trajectory is that Israeli economic development has been mostly driven by state-led initiatives rather than private or social initiatives such as a capitalist bourgeoisie class unlike in the Western trajectory (France, Britain and the USA) where capitalist bourgeoisie class has become primary initiator and driving force of economic modernization (Moore 1966). Namely, as Israeli state and state-like organizations such as the Histadrut have played the pivot role in launching and pushing forward economic development of the society, Israel followed a divergent trajectory from that of the West. More importantly, this economic divergence naturally impacted on other trajectories such as democratization.

CMT argues for the existence of a positive feedback loop between economic modernity and democratization, which means that the high economic growth of modern society would necessarily result in a liberal democratic regime. However, although Israel could be classified as an economically modern society by CMT as well as MMP because of its high economic growth, it was clearly shown that the high economic growth of Israel did not lead to a consolidated liberal democracy. By contrast, the non-liberal features of Israeli democracy outweigh the liberal façade of its democracy as it possesses many shortcomings, ranging from troubled civil-military relations to the exclusion of the non-Jewish citizens from political life, which undermines the liberal character of Israeli democracy. On other hand, a strong capitalist class - bourgeoisie - has not played a primary role in establishing and promoting 
democracy as in the Western trajectory. Instead, a small group of Zionist political elites was the main driving force in initiating political trajectory of Israeli modernity as the emergence of an independent capitalist class became possible only after the mid-1980s. In other words, the Israeli democratization has been an elite-led process rather than a bourgeoisie-led process as seen in the Western trajectory.

One of the most distinctive trajectories of Israel is its social life as the absence of secularization refutes CMT's hypothesis that secularization is irreversible as traditional values necessarily disappear in a modern society. The lingering religiosity of Jewish people has negatively affected Israeli secularization. As well as very observable place of the religion (Judaism) in the public sphere, the distorted state-religion relations and the unshaken standing of the religion in the various sectors of Israeli society today reflects this fact. Furthermore, although it can be classified as an economically modern society, Israel has never embarked on a far-reaching secularization program or there has never been a strong challenge to the religious status quo whose basis was laid in the early years of statehood. In the light of these, this lingering religiosity of Israel is more similar to non-Western cases such as Turkey where religiosity did not wane although it reached high economic growth in economic trajectory (Göksel 2015). After all, the unexpected outcome of Israeli social modernity renders the deterministic theorem of CMT as a failure in terms of comprehensively understanding modernity and modernization in non-Western societies.

A modernization process does not follow a fixed, single and determinate way, producing unexpected and uneven patterns over the years across the world. Based on the Israeli case studied throughout this thesis as well as other non-Western cases such as Iran (see Matin 2013; Göksel 2019), Turkey (see Göksel 2015; Göksel 2018a) and Azerbaijan (see Khalilzada 2019), the foremost finding of this article is that non-Western perspectives such as MMP and U\&CD are more accurate in terms of overcoming the Eurocentric bias and comprehending the uneven outcomes of modernization cases such as Israel. Hence, it can be argued that the idea of a universal modernity modelled after Western societies is a myth. We need more inclusive and non-determinist approaches capable of understanding the diversity of non-Western and many Western societies in our age. This is also necessary for future societies that will appear on the world stage in the near future. Challenging the Eurocentric impasse of the existing modernization theories, MMP and U\&CD can do that as this work and the others mentioned throughout this work show clearly and thus give a new way for the modernization studies.

\section{References}

Adelman, Jonathan (2008). Rise of Israel: A History of Revolutionary State (New York: Routledge).

Altun, Fahrettin (2002) Modernleşme Kuramı: Eleştirel Bir Giriş (Modernization Theory: A Critical Introduction) (İstanbul: Yöneliş Yayıncılık). 
Arat, Zehra F. (1988) 'Democracy and Economic Development: Modernization Theory Revisited', Comparative Politics 21 (1), pp. 21-36.

90.

Arnason, Johann P. (2000) 'Communism and Modernity', Daedalus 129 (1), pp. 61-

Arnason, Johann P. (2003) Civilizations in Dispute: Historical Questions and Theoretical Traditions (Leiden and Boston: Brill).

Barnett, Michael N. (ed) (1996) Israel in Comparative Perspective: Challenging the Conventional Wisdom (Albany: State University of New York). Press).

Beilin, Yossi (1992) Israel: A Concise Political History (New York: St. Martin's

Ben-Porat, Guy (2011) 'Inward Turns: Citizenship, Solidarity and Exclusion', in Guy Ben-Porat and Bryan S. Turner (eds.) The Contradictions of Israeli Citizenship (London and New York: Routledge), pp. 203-221.

Ben-Porat, Guy (2013) Between State and Synagogue: The Secularization of Contemporary Israel (New York: Cambridge University Press).

Ben-Porath, Yoram (ed) (1986) The Economy of Israel: Maturing through Crisis (Cambridge: Harvard University Press).

Coskun, Ismail. (1989) 'Modernleşme Kuramı Üzerine (On Modernization Theory)', IÜEF Sosyoloji Dergisi 3 (1), pp. 289-304.

Dussel, Enrique (1990) 'Eurocentrism and Modernity', Boundary 20 (3) (The Postmodernism Debate in Latin America), pp. 65-76.

Eisenstadt, S. Noah (2000) 'Multiple Modernities', Deadalus 129 (1), pp. 1-29.

Erkilet, Alev (2007) Toplumsal Yapı ve Değişme Kuramları (Societal Structure and Theories of Social Change) (Ankara: Hece Yayınları).

Etzioni-Halevy, Eva (1996) 'Civil-Military Relations and Democracy: The Case of the Military-Political Elites' Connection in Israel', Armed Forces and Society 22 (3), pp. 401417.

Fox, Jonathan, and Jonathan Rynhold (2008) 'A Jewish and Democratic State? Comparing Government Involvement in Religion in Israel with other Democracies', Totalitarian Movements and Political Religions 9 (4), pp. 507-531.

Giddens, Anthony (1996) Consequences of Modernity (Cambridge: Polity Press).

Göksel, Oğuzhan (2015) Assessing the Turkish Model: The Modernisation Trajectory of Turkey through the Lens of the Multiple Modernities Paradigm (Durham: Durham University). Available at Durham E-Theses Online: http://etheses.dur.ac.uk/11191/

Göksel, Oğuzhan (2016) 'In Search of a Non-Eurocentric Understanding of Modernization: Turkey as a Case of "Multiple Modernities", Mediterranean Politics 21 (2), pp. 246-267.

Göksel, Oğuzhan (2017) 'Revolutionary and Libertarian Islam: A Divergent Islamic Perspective on Modernity', ASOS: The Journal of Academic Social Science 5 (48), pp. 144162. 
Göksel, Oğuzhan (2018a) 'Uneven Development and Non-Western Modernities: A Historical Sociology Guide to the New Turkey', New Middle Eastern Studies 8 (1), pp. 6389.

Göksel, Oğuzhan (2018b) 'Eurocentrism Awakened: The Arab Uprisings and the Search for a "Modern" Middle East', in Hüseyin Ișıksal and Oğuzhan Göksel (eds.) Turkey's Relations with the Middle East: Political Encounters after the Arab Spring (New York and Heidelberg: Springer), pp. 33-51.

Göksel, Oğuzhan (2018c) 'The Turkish Economic Model Revisited, or: How We Have Missed Human Development', in Özgür Ünal Eriş and Ahmet Salih İkiz (eds.) The Political Economy of Muslim Countries (Newcastle upon Tyne: Cambridge Scholars Publishing), pp. 121-150.

Göksel, Oğuzhan (2019) 'Defying the System: The Origins of Anti-Westernism in the Non-Western World and the Case of Iran', Turkish Journal of Middle Eastern Studies 6 (2), pp. 13-42.

Göle, Nilüfer (2000) Melez Desenler: İslam ve Modernlik Üzerine (Hybrid Patterns: On Islam and Modernity) (İstanbul: Metis Yayınları).

Göle, Nilüfer (2002) 'Snapshots of Islamic Modernities’, Daedalus 129 (1), pp. 91117.

Göle, Nilüfer (2007) 'Batı-dış1 Modernlik: Kavram Üzerine' (On Non-Western Modernity), in Tanıl Bora and Murat Gültekingil (eds.) Modern Türkiye'de Siyasi Düşünce: Modernleşme ve Batıcılık (Political Thought in Modern Turkey: Modernizationa and Westernism) (İstanbul: İletişim), pp. 56-68. New York).

Grinberg, Lev (1991) Split Corporatism in Israel (New York: State University of

Grinberg, Lev (2017) 'Paving the Way to Neoliberalism', in Asa Maron and Michael Shalev (eds.) Neoliberalism as State Project (United Kingdom: Oxford University Press).

Gusfield, Joseph R. (1967) 'Tradition and Modernity: Misplaced Polarities in the Study of Social Change', American Journal of Sociology 72 (4), pp. 351-62.

Hanieh, Adam (2003) 'From State-led Growth to Globalization: The Evolution of Israeli Capitalism', Journal of Palestine Studies 32 (4), pp. 5-21

Hawthorn, Geoffrey (1987) Enlightenment and Despair (New York: Cambridge University Press).

Hazan, Reuven Y. (1999). 'Israel and the Consociational Model: Religion and Class in the Israeli Party System, From Consociationalism to Consensualism to Majoritarianism', in Kurt Richard Luther and Kris Deschouwer (eds.) Party Elites in Divided Societies: Political Parties in Consociational Democracy (London: Routledge), pp.164-189.

He, Chuanqi (2012) Modernization Science: The Principles and Methods of National Advancement (London: Springer).

Herzl, Theodor (1934) The Jewish State: An attempt At a Modern Solution of the Jewish Question (London: Central Office of the Zionist Organization).

Huntington, Samuel P. (1968) Political Order in Changing Societies (New Heaven: Yale University Press). 
Isserovitz, Haim (2015) 'BDS Movement Seeks to Empty Israel of Jews, Former Spanish PM Says’ Jerusalem Post, June 2015,

https://www.jpost.com/Middle-East/BDS-movement-seeks-to-empty-Israel-of-Jews-formerSpanish-PM-says-406608

Kaya, İbrahim (2004a) 'Modernity, Openness, Interpretation: A Perspective on Multiple Modernities', Theory and Methods 43 (1), pp. 35-57.

Kaya, İbrahim (2004b) Social Theory and Later Modernities: The Turkish Experience (Liverpool: Liverpool University Press).

Khalilzada, Javadbay (2019) 'Modernization and Social Change in Azerbaijan: Assessing the Transformation of Azerbaijan through the Theories of Modernity', New Middle Eastern Studies 9 (2), pp. 167-188.

Kimmerling, Baruch (1999) 'Religion, Nationalism and Democracy', Constellations 6 (3), pp. 339-369.

Laqueur, Walter (1972) A History of Zionism: From the French Revolution to the Establishment of the State of Israel (New York: MJF Books).

Lerner, Daniel (1958) The Passing of Traditional Societies: Modernizing the Middle East (New York: Free Press).

Lerner, Hanna (2004) 'Democracy, Constitutionalism, and Identity: The Anomaly of the Israeli Case', Constellations 11 (2), pp. 237-257.

Lerner, Hanna (2013) 'Permissive Constitutions, Democracy, and Religious Freedom in India, Indonesia, Israel, and Turkey', World Politics 65 (4), pp. 609-55.

Matin, Kamran (2007) 'Uneven and Combined Development in World History: The International Relations of State-formation in Premodern Iran', European Journal of International Relations 13, pp. 419-447.

Matin, Kamran (2013) Recasting Iranian Modernity (New York: Routledge).

Mintz, Alex (1983) 'The military-industrial complex: The Israeli case' Journal of Strategic Studies 6 (3), pp.103-127.

Moore, Barrington (1966) Social Origins of Dictatorship and Democracy: Lord and Peasant in the Making of Modern World (Boston: Beacon Press).

Ottolenghi, Emmanuel (2002) 'Religion and Democracy in Israel', The Political Quarterly 71, pp. 39-49.

Peri, Yoram (1983) Between Battles and Ballots: Israeli Military in Politics (New York: Cambridge University Press). Publishers).

Preston, Peter (1996) Development Theory: An Introduction (USA: Blackwell

Preyer, Gerhard and Sussman Gerald (ed) (2016) Varieties of Multiple Modernities (Boston: Brill).

Ram, Uri (2008) 'Why Secularism Fails? Secular Nationalism and Religious Revivalism in Israel', International Journal of Politics Culture and Society 21, pp. 57-73.

Rubinstein, Amnon (1967) 'State and Religion in Israel', Journal of Contemporary History 2 (4), pp. 107-121. 
Schiff, Rebecca L. (1992) 'Civil-Military Relations Reconsidered: Israel as an 'Uncivil' State', Security Studies 1 (4), p. 636-658.

Shalev, Michael (1992) Labor and Political Economy in Israel (Oxford: Oxford University Press).

Sheffer, Gabriel and Oren Barak (2013) Israel's Security Networks: Theoretical and Comparative Perspective (New York: Cambridge University Press).

Smooha, Sammy (1990) 'Minority Status in an Ethnic Democracy: The Status of the Arab Minority in Israel', Ethnic and Racial Studies 13 (3), pp. 389-413.

Smooha, Sammy (1992) Arabs and Jews in Israel: Change and Continuity in Mutual Intolerance (Boulder: Westview Press).

Smooha, Sammy (2002) 'The Model of Ethnic Democracy: Israel as a Jewish Democratic State', Nations and Nationalism 8 (4), pp. 475-503.

Sunar, Lütfi (ed) (2016) Eurocentrism at Margins: Encounters, Critics and Going Beyond (New York: Routledge).

Tepe, Sultan (2008) Beyond Sacred and Secular: Politics of Religion in Israel and Turkey (California: Stanford University Press).

Tipps, Dean C. (1973) 'Modernization Theory and the Comparative Study of Societies: A Critical Perspective', Comparative Studies in Society and History 15 (2), pp. 199-226.

Wagner, Peter (2000) 'Modernity - One or Many?', in Judith Blaue (ed) The Blackwell Companion to Sociology (Oxford: Blackwell), pp. 30-42.

Wagner, Peter (2012) Modernity: Understanding the Present (Cambridge: Polity).

Wittrock, Björn (2002) 'Modernity: One, none or many? European Origins and Modernity as a Global Condition', in Samuel N. Eisenstadt (ed) Multiple Modernities (New Brunswick: Transaction), pp. 31-60.

World Bank (2018) Israel Country Data 2018, https://data.worldbank.org/country/israel

Yiftachel, Oren (1999) 'Ethnocracy: The Politics of Judaizing Israel/Palestine', Constellations 6 (3), pp. 364-390.

Yücedă̆, İhsan (2010) 'Nilüfer Göle'de Bat1-dışı Modernliği Anlamak', E-Şarkiyat İlmi Araştırmalar Dergisi 3, pp. 69-82.

\begin{abstract}
About the Author
Erdem Sarıaydın is a PhD Candidate at the Department of International Relations and Regional Studies, National Defence University, Turkey. He completed his Master's Degree in Political Science and International Relations at Istanbul 29 Mayis University, Turkey in 2018. His research interests are studies of modernization, non-Western modernization theories, globalization and economic nationalism. His works have been published in academic journals such as Mevzu - Journal of Social Science and New Middle Eastern Studies. Email: erdemsaraydn@gmail.com
\end{abstract}

